\title{
The Role of Organizational Commitments in Mediating the Locus of Control on Auditor Performance
}

\author{
Siti Sundari*, Sri Hastuti, Rida Perwita Sari, Rika Puspita Sari \\ Universitas Pembangunan Nasional "Veteran” Jawa Timur, Surabaya 60294, Indonesia
}

*Corresponding author:

E-mail:

sitisundari.ak@upnjatim.ac.id

\begin{abstract}
This study aims to prove the role of organizational commitment as a mediator on the effect of locus of control on auditor performance. The research data were collected by questionnaire, with a sample of 88 auditors working in public accounting firms in the cities of Surabaya and Malang, East Java. Data analysis was done using Path Analysis with Smart PLS software. The research shows that locus of control has a positive effect on auditor performance, organizational commitment has a positive impact on auditor performance, and organizational commitment is a mediator of locus of control on auditor performance.
\end{abstract}

Keywords: Locus of control, organizational commitment, auditor performance

\section{Introduction}

Auditor performance is an auditor's ability to draw findings or examination results from audit activities on management and financial responsibilities carried out by an audit team. Less conducive working conditions can affect an auditor's performance, which acts public trust in said public Accountant as an independent party. Factors that influence auditor performance include locus of control and organizational commitment. Auditor performance as a result of the work of public accountants who carry out objective assignments, examinations of the financial statements of a company or other organization, determining whether, in all material respects, the financial reports (the financial position and results of operations of a company) are fairly presented by generally accepted accounting principles (Mulyadi, 2014). The performance of the Public Accounting Firm is determined mainly by the performance of the auditor. Ideally, in carrying out their profession, auditors must obey the rules of professional ethics. The success and implementation of a person in a field of work are determined by the level of competence, professionalism, and the locus of control possessed by an auditor.

Rotter first introduced the concept of locus of control in 1966. Locus of control is an aspect of personality possessed by each individual regarding their confidence in their ability to control their destiny; it can be divided into internal Locus of control and external Locus of control (Sarita \& Agustia, 2009). According to Rotter, employees with an internal locus of control believe in their abilities, experience, and skills, which will bestow them with rewards and achievements. In contrast, employees with an external locus of control believe in others' luck and strength (Khushk, 2019). Auditors with an internal locus of management will provide a more positive contribution to performance in carrying out audit tasks. This is because internal control can be seen through capabilities and actions, influencing successes, and failures upon doing work. Auditors with an external locus of control, on the other hand, feel that there are forces (authorities) beyond themselves that support the results of their work.

Another factor that can affect an auditor's performance is their commitment to the area they are engaged in. Define responsibility as a situation where an individual sits with the organization and its goals and desires to maintain their membership in the said organization (Robbins \& Judge, 2013).

\section{How to cite:}

Sundari, S., Hastuti, S., Sari, R. P., \& Sari, R. P. (2021). The role of organizational commitments in mediating the locus of control on auditor performance. $3^{\text {rd }}$ Economics, Business, and Government Challenges 2020. NST Proceedings. pages 1-5. doi: $10.11594 /$ nstp.2021.1301 
An organizational commitment is one's ability to identify their involvement in an organization. Auditors committed to their organization will show the right attitude and leadership style, have the passion for defending their organization, improve their performance, and have absolute confidence to realize the organization's goals (Arifah et al., 2012).

Establishing good performance management requires an exceptional organizational commitment from every individual in the organization. Such responsibility can be forged if individuals in the organization know their rights and obligations within the organization without minding their positions. The achievement of organizational goals is the collective work of every organization member (Akriyanto, 2012).

Declining public confidence in the quality of services provided by public accountants in Indonesia is increasingly visible along with the arise economic crises in Indonesia and accounting manipulation phenomena, beginning in 2002 with the disclosure of cases involving public accounting firms incorporated in the Big Five, Arthur Andersen, known as the Enron case; and then the Great River, Chemical Pharma, and Worldcom cases involving accounting firms that have been believed to have high audit quality. In the Great River case, the Indonesian finance minister, commencing on November 28, 2006, has frozen the permit of the Public Accountant (AP) Justinus Aditya Sidharta for two years. There was also the Telkom case that occurred in 2008, ending with the shutdown of the Edy Priyanto Public Accounting Firm. There are still many other cases of violations toward the accountant's code of ethics, so it is deemed necessary to continue to review auditors' performance to increase public trust in company performance, which can be seen from the opinions published by the Public Accounting Firm. This has motivated researchers to focus their research on auditor performance.

This study aims to prove the existence of (a) the effect of locus of control on auditor performance, (b) the impact of organizational commitment on auditor performance, and (c) the role of organizational commitment as a mediator on the effects of locus of control on auditor performance. Professional auditors are required to have special skills and expertise. High job demands and the ability to be experienced are challenges that must be met by an auditor. An independent auditor will make decisions not based on the interests of the client, personal or other parties, but based on the facts and evidence collected during the audit (Ermawati et al., 2014). A public accounting firm's performance quality is highly determined by its auditors' performance, hence its position in the limelight, for both clients and the public, when it comes to assessing the results of conducted audits.

Finally, this research is expected to contribute to improving auditor performance, which can be indicated by reducing the number of violations committed by public accounting firms and increasing public confidence in the information contained in financial statements so that it can be used in decision making for interested parties. Results are also expected to act as additional empirical research results and strengthen existing theories.

\section{Material and Methods Operational definitions}

\section{Locus of control/LOC $(X)$}

Locus of control (LOC) is a person's perspective on an event; how strongly he believes that he controls his situation and daily life experience.

\section{Organizational commitment/OC $(Z)$}

Organizational commitment (OC) is the degree to which the auditor believes and accepts its goals and will remain within (will not leave) the organization.

\section{Auditor performance/AP $(Y)$}

Auditor Performance (AP) is a condition or results achieved by an external auditor in examining and evaluating the client's company's financial statements, whether they have been presented relatively by generally accepted accounting principles. 


\section{Population and sample}

The population used in this study are all public accounting firms located in East Java with their external auditors (public Accountant) its unit of analysis, with a total sample of 88 auditors spread throughout Surabaya and Malang sampled randomly using simple random sampling.

\section{Analysis method}

Data analysis was done using Partial Least Square (PLS), assisted with Smart PLS 3.0 software.

The path analysis model of all latent variables in this study was constructed in two stages (Sholihin et al., 2013).

a. Estimating the direct effect; the effect of locus of control on auditor performance.

b. We estimate the indirect effect simultaneously using triangle SEM mode, determining the outcome of locus of control and organizational commitment toward auditor performance.

To prove the mediation effect, path coefficients must be significant in both stage 1 and stage 2 . The Variance Accounted for (VAF) method can be used to determine the mediation status (Hair et al., 2014):

$$
\mathrm{VAF}=(\mathrm{P} 12 \times \mathrm{P} 23) /(\mathrm{P} 12 \times \mathrm{P} 23+\mathrm{P} 13)
$$

\section{Results and Discussion}

Table 1. R Square

\begin{tabular}{ll}
\hline & R Square \\
\hline AP & 0.361981 \\
LOC & \\
OC & 0.301207 \\
\hline
\end{tabular}

The $\mathrm{R}^{2}$ value of our model is $=1-[(1-0.3012)(1-0.3619)]=0.5541$, meaning that the model can explain $55.41 \%$ of the variability of auditor performance influenced by the locus of control and organizational commitment, while the rest $(100 \%-55.41 \%=44.59 \%)$ can be explained by factors not mentioned this research model.

Table 2. Path Coefficients (Mean, STDEV, T-Values)

\begin{tabular}{llllll}
$\begin{array}{l}\text { Original } \\
\text { Sample }(\mathrm{O})\end{array}$ & $\begin{array}{l}\text { Sample Mean } \\
(\mathrm{M})\end{array}$ & $\begin{array}{l}\text { Standard } \\
\text { Deviation } \\
(\mathrm{STDEV})\end{array}$ & $\begin{array}{l}\text { Standard } \\
(\mathrm{STERR})\end{array}$ & Error & $\begin{array}{l}\text { T Statistics } \\
(\mid \mathrm{O} / \mathrm{STERR})\end{array}$ \\
0.221972 & 0.237418 & 0.099580 & 0.099580 & 2.229092 \\
0.548823 & 0.562781 & 0.054239 & 0.054239 & 10.118675 \\
0.450497 & 0.453456 & 0.084697 & 0.084697 & 5.318910 \\
\hline
\end{tabular}

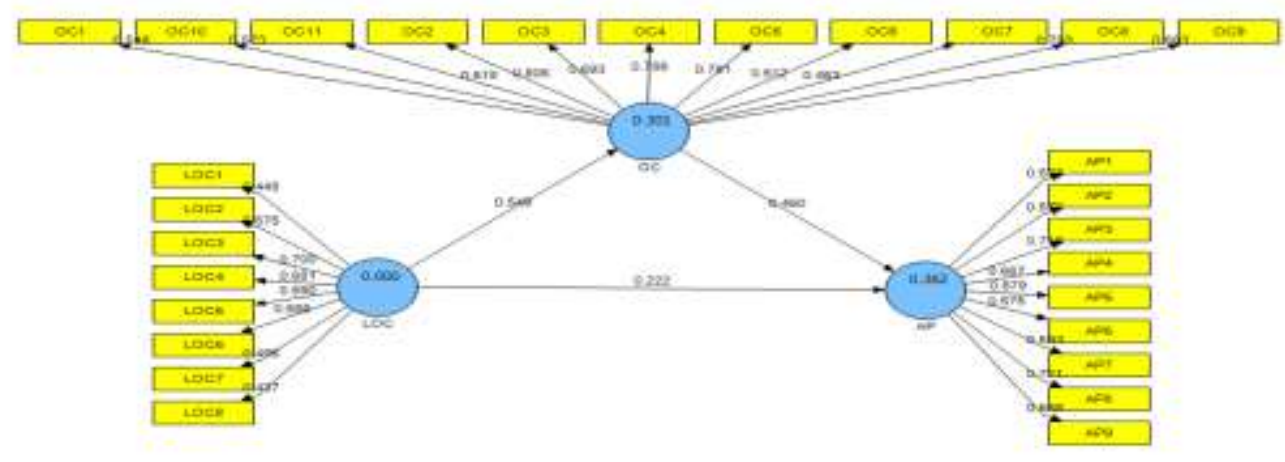

Figure 1. Outer model with factor loading, path coefficient, and R-Square 
a. LOC, which has a path coefficient of 0.221972 , has a positive effect on AP. The t-statistic value (2.229092) is greater than the cost of $Z_{\alpha=0.05(5 \%)}=1.96$. LOC has a positive effect and significant impact on AP.

b. LOC, which has a path coefficient of 0.548823 , has a positive effect on OC. The t-statistic value (10.118675) is greater than the cost of $Z_{\alpha=0.05(5 \%)}=1.96$. LOC has a positive effect on the significant impact on OC.

c. OC, which has a path coefficient of 0.450497 , has a positive effect on AP. The t-statistic value (5.318910) is greater than the cost of $Z_{\alpha=0.05(5 \%)}=1.96$. meaning that $\mathrm{OC}$ has a positive effect and significant impact on AP.

The magnitude of the indirect influence of LOC on AP through OC is calculated as follows:

$$
=0.548823 \times 0.450497=0.2472
$$

Therefore, the magnitude of the indirect influence of LOC on AP through OC is 0.2472.

The magnitude of the path coefficient, the indirect effect (0.2472), is greater than the LOC's direct impact on the AP (0.2219), meaning OC is a mediating variable on the LOC's effect on the AP. According to Hair et al. (2014), we can determine whether a variable is a mediator variable or not using the Variance Accounted For (VAF) method.

$$
V A F=\frac{P_{12} \times P_{23}}{P_{12} \times P_{23}+P_{13}}=\frac{0.549 \times 0.450}{0,549 \times 0,450+0,222}=\frac{0.24705}{0.46905}=0.52670=52.67 \%
$$

Our model has a VAF of $52,67 \%$, which is within the interval $20 \%<$ VAF $<80 \%$. Therefore, we can conclude that organizational commitment (OC) is a mediator variable that partially mediates the effect of locus of control on auditor performance (Hair et al., 2014). Through organizational commitment, locus of control has a positive effect and significant impact on auditor performance.

Analysis results show that the locus of control influences auditors' performance in public accounting firms located in Surabaya and Malang, East Java. Locus of control is a person's perspective on an event; how strongly they believe that they control their situation and experience in daily life (Khushk, 2019). Locus of power can be divided into internal Locus of control and external Locus of control (Engko \& Gudono, 2007). Locus of control determines the core of one's command of themself. An auditor with a high internal locus of power has substantial control within themself; within this context, everything related to taken actions and obtained results is mostly supported by factors within the auditor themself. Auditors with an internal locus of control tend to be harder to pressure or get influenced by factors beyond their control. Their belief in positive aspects of auditing within the code of ethics and the strength of their internal locus of control often cause their decision to be firmly given. Other factors originating outside of their authority are often rejected, so the auditor would not accept audit dysfunction behavior. This finding similar to the research, which states that internal auditors with a tendency of internal locus of control have better performance (Patten, 2005). Likewise, also found that individual auditors' characteristics affect auditor performance; auditors who have an internal locus of control perform better (Kartika, 2007).

Statistical analysis results show that organizational commitment affects auditors' performance at public accounting firms located in Surabaya and Malang. Organizational commitment is a psychological bond between employees and their organization that is characterized by the presence of 1) Trust and acceptance of the goals and values of the organization, 2) Willingness to put in a genuine effort to benefit the organization, 3) Desire to maintain membership in the organization. Auditors with high organizational commitment will have a sense of belonging to the organization they work at. They will be willing to put in their best effort for their organization, therefore improving their performance. The existence of a commitment can act as an encouragement for someone to work better (Trisnaningsih, 2007). Ghorbanpour et al. (2014) found that organizational commitment has a positive and significant effect on auditor performance in the certified accountant community of Tehran and Shiraz.

Results also show that locus of control contributes to the improvement of auditor performance through organizational commitment. In other words, organizational commitment is a mediator on the influence of locus of control on the performance of auditors working at public accounting firms in Surabaya and Malang. Locus of control is a person's view of success or failure in carrying out their work; whether the results obtained influence external factors or internal factors. Auditors with an internal locus of control tend to be more successful in their careers than auditors with an external locus of control. Auditors with an internal locus of control tend to have a higher level of work, faster promotion, and more significant income (Engko \& Gudono, 2007). Internal locus of 
control will encourage auditors to survive in the organization, meaning that auditors with an internal locus of control will have higher organizational commitment than auditors with an external locus of control. The internal locus of control increases employee commitment and reduces labor turnover at Jubilee Insurance Company Limited in Kenya (Wangui, 2015). Organizational commitment shows a person's power in identifying his involvement in an organization. Organizational commitment, therefore, will lead auditors to a sense of belonging towards their organization. Once the auditor feels their soul is bound to existing corporate values, they will feel comfortable at work. They will also be motivated to maximize their efforts to provide the best for the organization, perpetually improving their performance. High organizational commitment will encourage auditors to work better for the organization's benefit to enhance auditor performance.

\section{Conclusion}

Based on analysis results and discussions, we can conclude that locus of control contributes to improving auditor performance, organizational commitment contributes to improving auditor performance, and organizational commitment acts as a mediating variable on the contribution of locus of control to improving auditor performance at public accounting firms in Surabaya and Malang, East Java.

Results of this study act as an input to the public accounting firm, specifically in recruiting auditors. Public accounting firms need to pay attention to a candidate's locus of control and organizational commitment of prospective auditors because both of these factors contribute to improving auditor performance. Future research can be done by adding more variables to affect auditor performance, such as leadership style and gender. This study's limitation is the number of samples that are not too large for the East Java region's size because several public accounting firms have either been closed or changed their address.

\section{References}

Akriyanto, R. (2012). The influence of independence, leadership style, organizational commitment and understanding of good governance on auditor performance (Empirical study on auditors in KAP Surakarta and Yogyakarta regions). Muhammadiyah Surakarta University.

Arifah, N., Asri, U., \& Rahmawati. (2012). Effect of auditor independence, organizational commitment, and leadership style on auditor performance. Hasanuddin University.

Engko, C., \& Gudono. (2007). Effect of task complexity and locus of control on the relationship between leadership style and auditor job satisfaction. JAAI, 11 (2), 105-124.

Ermawati, M. D., Sinarwati, N. K., Sujana, E. (2014). Pengaruh role stress terhadap kinerja auditor dengan emotional quotient sebagai variabel moderating (Studi empiris pada kantor akuntan publik di Bali). Jurnal Ilmiah Mahasiswa Akuntansi, 2(1), 1-6. DOI: http://dx.doi.org/10.23887/jimat.v2i1.2957

Ghorbanpour, Z., Dehnavi, H. D., \& Heyrani, F. (2014). Investigating The Effect of Organization Commitment on Performance of Auditors in The Community of Certified Accountants. Interdisciplinary Journal of Contemporary Research in Business, $199-209$. https://doi.org/10.1021/la202487v.

Hair, Joseph E, Jr et al. (2014). A primer on partial least squares structural equation modeling (PLS-SEM). California. USA: SAGE Publications, Inc.

Kartika, I., \& Wijayanti, P. (2007). Locus of control as antecedents of employee performance relationship and acceptance of dysfunctional Audit Behavior (a study on government auditors was working at BPKP I Central Java and DIY). Journal of Auditing and Professional Ethics, National Symposium on Accounting, X, 105-109.

Khushk, A. A. (2019). Impact of Locus of Control (LOC) and organizational commitment on employee performance-study of service sector, Pakistan. International Journal of Law and Peace Works, 6(5), 1-7. https://doi.org/10.5281/zenodo.2660275. (2019).

Mulyadi. (2014). Auditing. Book 1, th Edition. Jakarta: Salemba Four.

Patten, D. M. (2005). An analysis of the impact of locus-of-control on internal auditor job performance and satisfaction Title. Managerial Auditing Journal, 20(9), 1016-1029. (2005).

Robbins S. P., \& Judge. (2013). Organizational behavior. Jakarta; Four Salemba.

Sarita, J., \& Agustia, D. (2009). the influence of situational leadership style, work motivation, locus of control on job satisfaction and job performance of auditors. Journal of the National Accounting Symposium XII (SNA 12), 1-5.

Sholihin, Mahfud \& Ratmono, D. (2013). SEM-PLS analysis with Warp PLS 3.0 (Ed 1). Yogyakarta: Andi Offset, CV Andi Offset.

Trisnaningsih, S. (2007). Auditor independence and organizational commitment as mediation influence of understanding good governance, leadership style, and organizational culture to auditor performance. National Symposium on Accounting, X, 102-110.

Wangui, W. P. (2015). The influence of locus of control on employee commitment and labour turnover: A case study of jubilee insurance company limited. The University of Nairobi. 